Ankara Üniversitesi Eğitim Bilimleri Fakültesi Dergisi, yıl: 2004, cilt: 37, sayı: 2, 61-82

\title{
Küreselleşme, Bilgi Toplumu ve Eğitim
}

\author{
Refik BALAY
}

ÖZ: Bu araştırmanın amacı, küreselleşme, bilgi toplumu ve eğitim hakkında daha önce ortaya konan görüşlerin bir analizini yapmak ve son gelişmeler ışı̆̆ında eğitimde yaşanan değişmeleri irdelemektir. Bu bağlamda küreselleşme, küreselleşmenin olumlu ve olumsuz yönleri, bilgi toplumu, eğitim sürecinde değişim, değişim sürecinde eğitim programları, okul, okul yöneticileri, öğretmen ve öğrenci konuları üzerinde yoğunlaşılmış ve bunların eğitime yansıyış biçimi tartışılmıştır.

Anahtar Kelimeler: Küreselleşme, bilgi toplumu ve eğitim.

\section{Globalization, Information Society and Education}

ABSTRACT: The aim of this study is to analyze the thoughts previously discussed on globalization, information society, education and handle experienced changes in the light of last developments. In this context, we focused on globalization, the positive and negative aspects of globalization, information society, the changes took place in educational process, subjects of educational programs, school, school administrators, teachers and students and their reflections to education were discussed.

Key Words: Globalization, information society, and education

\section{Giriş}

İçinde yaşadığımız dünyanın son zamanlardaki en önemli olgusu küreselleşme olgusudur. İnsan ve toplumların yeryüzünde olup bitenlerden giderek daha çok haberdar olmaları, birbirlerinin eylem ve deneyimlerinden etkilenmeleri, bunları paylaşmaları ve yaymaları ile ortaya çıkan süreci her

\footnotetext{
* Harran Üniversitesi Fen Edebiyat Fakültesi Eğitim Bilimleri Bölümü Öğretim Üyesi
} 
defasında yeniden irdelemek gerekir. Zira küreselleşme kavramı yeni bir kavram olmasına ve bugüne kadar hakkında çok şey yazılmasına karşın halen devam eden bir süreçtir. $\mathrm{Bu}$ sürecin yarattığı deneyimler yayılıp, paylaşıldıkça, neden ve sonuçlarının daha iyi kavranması mümkün hale gelecek, ayrıca bundan sonra ortaya çıkabilecek muhtemel eğilimler de daha iyi anlaşılacaktır.

Toplum yapısında meydana gelen gelişmeler; nüfusun farklılaşması, ekonomik dönüşüm, aile biçimleri ve yaşam tarzlarının değişmesi küreselleşmenin yol açtığ 1 önemli değişim konularından sadece bazılarıdır. Bütün bunlar bilginin küresel düzeyde paylaşımı ve yayılması ile yakından ilişkili görünmektedir. Bu araştırma, küreselleşme ile ortaya çıkan sosyal, politik, ekonomik ve kültürel değişim alanlarını incelemekten çok, küreselleşme ve onun yansımalı bir süreci olarak öne çıkan bilgi toplumu ve eğitimdeki değişim konuları hakkında bilgi vermek, daha önce bu konuda ortaya konan görüşlerin bir analizini yaparak, bu alanda ortaya çıkan yeni eğilimleri tartışmayı amaçlamaktadır.

\section{Küreselleşme Olgusu}

Globalleşmenin Türkçe karşıllı̆ı olarak kullanılan "Küreselleşme", ekonomik içerikli bir kavram olarak ortaya çıkmıştır (Tezcan, 1996, 187). $\mathrm{Bu}$ açıdan terim, belirsizlik içerse de son yıllarda dünya ölçeğinde ortaya çıkan ilişkiler ve yeni yaşam biçimleri küreselleşmenin neliği konusunda bazı fikirler vermektedir.

Toulmin'e $(1999,906)$ göre insanlar ve toplumlar gittikçe üst üste binişen hatta ülkelerin sınırlarını bile aşan faaliyetlere girmiştir. Seyahat, iletişim, finansman, ticaret, spor müsabakaları, meslekler ve hatta popüler müzik artık tek bir ülkenin sınırları içine hasredilemez olmuştur. Buna benzer bir çok ilişki ve faaliyet, uluslararası bir niteliğe kavuşmuştur. $\mathrm{Bu}$ açıdan bakıldığında küreselleşmenin, tarihsel bir olgu ve süreç olarak, insan ve toplumlar arasındaki ilişkileri daha çok zenginleştirdiği söylenebilir. Değişik ülkelerden insanlar bir araya gelmekte, mal, hizmet ve fikir alışverişinde bulunmakta ve birbirlerinin deneyimlerinden yararlanmaktadırlar. Bütün bu yaşananlar, insanların, ulusal düzeydeki düşünce ve ilişki biçimlerinden, uluslararası ölçekte yeni bir ilişki ve düşünme biçimlerine geçtiklerini göstermektedir.

Buna göre küreselleşme, dünya ölçeğinde ekonomik, siyasal ve kültürel bütünleşme, fikirlerin, görüşlerin, pratiklerin, teknolojilerin küresel düzeyde kullanılması, sermaye dolaşımının evrenselleşmesi, ulus-devlet sınırlarını aşan yeni ilişki ve etkileşim biçimlerinin ortaya çıkması, mekanların yakınlaşması, dünyanın küçülmesi, sınırsız rekabet, serbest dolaşım, pazarın 
dünya ölçeğinde büyümesi ve ulusal sınırların dışına çıkması, kısaca dünyanın tek pazar haline gelmesidir (Kaçmazoğlu, 2002, 49).

Diğer yandan küreselleşme, "rekabet edebilirlik" kavramı ile de yakından ilişkilidir. Küreselleşme ile ortaya çıkan bu kavram, bir ülkenin, "ulusal politikasını" küresel pazarın gereklerini, rakiplerine göre daha etkili karşılayabilme yeteneğinde olacak şekilde sürdürebilmesini ifade etmektedir (Toulmin, 1999, 906).

Küreselleşme, ulusal hükümetlerin ekonomik rollerini azaltmış, küresel rekabetin ülkelerden çok, uluslararası şirketler arasında olmasına yol açan bir süreci hızlandırmıştır. Artık küresel rekabet, İngiltere ile Almanya, Japonya ile ABD veya Avrupa ile ABD arasında olmaktan çok, Fuji ile Kodak, Boeing ile Airbus, Compaq ve Toshiba arasında olmaktadır. Bu süreç aynı zamanda iş dünyası ile ulus devletler arasında giderek artan bir amaç çakışmasının varlığını da haber vermektedir. Uluslararası şirketlerin en ucuz emeği, en düşük vergileri ve en az çevre koruma yasalarını talep etmeleri daha şimdiden bu sürecin yoğun bir çıkar ve amaç çatışması doğuracağını göstermektedir (Toulmin, 1999, 905).

Hangi açıdan ele alınırsa alınsın, teknolojik gelişmeler, ekonomik ve ideolojik etkenler küreselleşmenin ana etkenleri arasında sayılabilir. Bilişim teknolojilerinin ucuzlaması ve yaygınlaşması bilgi akışını hızlandırmış, zaman, mekân ve mesafe algılamalarını değiştirmiş, kültürleşme sürecine ivme kazandırarak küresel değerlerin oluşmasına zemin hazırlamıştır (Yurdabakan, 2002, 63). Halen devam eden bu süreç, yeryüzü toplumlarının tümünü ilgilendirdiği için üzerinde durulması gereken bir olgudur.

\section{Küreselleşmeye İlişkin Olumlu ve Olumsuz Yaklaşımlar}

Kurul Tural (2004, 62-63), küreselleşmeyi farklı boyutlarda olumlayan ve olumsuzlayan görüşlerin olduğu gerçeğini aktarmaktadır. Olumlu söylemlerden ilkine göre toplumlardaki eşitsizliklerin kaynağ 1 yapısal değil, bireyseldir. Bireyin işsizliğinden ekonomik süreçler değil, değişime uyum sağlayamayan birey sorumludur. İkinci olumlu söylem, dikkati adalet kavramına yöneltmektedir. Buna göre küreselleşen dünyaya uyum sağlayamayan bireylerin gerçekte hak etmedikleri "refah hakları" savunulduğu sürece, ekonomik girişimcilik engellenir. Bu durum sorunlu adalet kavramının sürekli biçimde beslenmesine neden olur. Üçüncü olumlu söylem, dikkati daha çok devletin toplumsal ve ekonomik yaşamı düzenleme işlevine yöneltmektedir. $\mathrm{Bu}$ söyleme göre devlet, toplumsal ve ekonomik yaşamı düzenleme işlevini ne ölçüde aza indirip, bunu büyük ölçüde bireysel firsat eşitliğine dayalı ahlak ilkesi çerçevesinde değerlendirirse o ölçüde demokratik olabilir. Böylece demokratik devlet, daha çok "bireycilik" ve özgürlük anlayışı ile daha az devlet müdahalesinin gerektirdiği özelliklere sahip olarak, bireyler için daha fazla yararlar sağlayabilir. 
Diğer yandan küreselleşmeyi olumsuzlayan söylemler de vardır. Küreselleşmeyi olumsuzlayan birinci söylem, onu "ideolojik bir kurgu" olarak değerlendirmektedir. $\mathrm{Bu}$ söyleme göre küreselleşme, küresel sermeyenin ve serbest pazarın dünya üzerindeki egemenliğini pekiştirmeye yarayan ideolojik bir araçtır. $\mathrm{Bu}$ haliyle küreselleşme karşı konulması gereken bir süreç olarak öne çıkmaktadır. İkinci olumsuz söylem, küreselleşmenin kültürel boyutuna vurgu yapmaktadır. Buna göre küreselleşme, Batı değer ve yaşam biçimlerinin hakim olduğu tek bir dünya yaratarak, dünya ölçeğinde kültürel birörnekliği niteleyen bir süreç olması nedeniyle olumsuz olarak değerlendirilmektedir. Küreselleşmeye ilişkin üçüncü olumsuz söylem ise, onun, kendine özgü işleyiş yasaları olan, bağımsız ekonomik bir süreç olduğu görüşüne dayanmaktadır. Bu söyleme göre küreselleşmeyi "kaçınılmaz ve karşı konulmaz bir süreç" olarak görmek demek, küresel sermaye hareketlerine direnmemeyi ve minimal devlet anlayışının yanında yer almayı ifade eder.

Küreselleşmeye ilişkin olumlu ve olumsuz söylemler, söz konusu sürecin yarattığı olumlu ve olumsuz etkiler bağlamında daha yakından ele alınabilir. Zira her değişim ve dönüşümün olumlu etkileri olduğu gibi olumsuz etkileri de vardır. Küreselleşmeye ilişkin olumlu ve olumsuz etkiler şöyle özetlenebilir (Bilhan,1996, 179-180, 183; Tezcan, 1996, 192-194):

\section{Olumlu Etkiler}

- Küreselleşme ile zaman ve mekan sınırları yüzyıllar boyunca adım adım genişleyerek günümüze kadar gelmiş, dünyada olup biten her şey bütün insanlığa mal edilmeye başlanmıştır.

- İnsanlığın ortak değerleri oluşmaya başlamış, insan ve onun eserleri, yani kültür ve uygarlık yeni baştan anlamlandırılmıştır.

- İnsan hakları, özgürlük, adalet ve eşitlik gibi kavramlar yaygınlaştıkça, insanlar yeni bir kişilik kazanmaya, kendine inanmaya ve güven duymaya başlamıştır. Kendini tanıyan ve giderek kendine güvenen insan, kendi değerini keşfetmiş, hiç bir kimseye ve kuruma kul köle olmaması gerektiğini anlamıştır.

- Her ülkenin sadece seçkin bir kesimini eğitmenin çıkar yol olmadığı, kalkınma için halkın tabanına kadar ulaşan bir eğitim sistemiyle kitlesel olarak yetişmiş nitelikli nüfusa ihtiyaç olduğu gerçeği kavranılmıştır.

- Sağlık alanında bir çok hastalık ülkelerin işbirliği ile yenilmiş, bebek ve çocuk ölümleri azalmış, insanların yaşam süreleri uzamış, sağlıklı yaşam olanakları genişlemiştir.

- Ülkeler arasında çeşitlenmiş işgücünün serbest dolaşımı sağlanmış, üretim ve tüketimde rekabet artmış, dünyanın neresinde olursa olsun insanlar 
birbirlerinin üretiminden faydalanmaya ve birbirlerinin ürünlerini tüketmeye başlamıştır.

- İnsanlar arasında yeni ve ortak yaşam biçimleri belirmeye başlamış, ortak eğitim politikaları yoluyla ülke vatandaşları arasında ortak kavrayış ve anlayışlar gelişmiştir.

\section{Olumsuz Etkiler}

- Küreselleşen dünyada güçlü devletlerle bütünleşmek zorunda kalan gecikmiş ulusal devletler ekonomik, siyasal ve kültürel açıdan büyük devletlerin açık etkisine maruz kalmıştır. Bunun sonucunda bir tür bağımlılık durumu oluşmuş, ulusal sınırlar yok sayılmış, milli egemenlik ve bağımsızlık gibi kavramların içi boşaltılmış, emperyalist amaçlar küreselleşme adı altında meşrulaştırılmaya çalışılmıştır.

- Küreselleşme toplumları birbirinden farklı ve hatta zıt olan iki yöne doğru çekmeye başlamıştır. Birinci yönde toplumlar daha da yakınlaşıp bütünleşirken, öteki yönde ulusalcılık, etnik ulusalcılık ile parçalanma sürecine sokulmuştur. Birbirine zıt bu iki durum, üye ülkeler için bir yandan küreselleşme sürecinin dışında kalmamak, öte yandan ulusal bütünlüğü korumak gibi bir ikilem yaratmıştır.

- Dünyadaki ülkelerin üretim gücü ve tüketim olanakları aynı değildir. $\mathrm{Bu}$ yönden sanayileşmesini tamamlamış ülkeler daha üstün durumdadır. Küreselleşme zenginleşmenin ve refahın dağılımı kadar, fakirlik ve sefaletin dağılımını da hızlandırmıştır.

- Dünyada eğitim sürecine katılan insanların sayısı giderek artmaktadır. Her kademedeki eğitim kurumları teknolojik imkânları kullanarak insanların bilgi ve beceri düzeylerini yükseltmektedir. Buna karş1lık eğitimden yararlanmayanların sayısında bir azalma değil, artma olduğu ileri sürülmüştür.

Görüldüğü gibi küreselleșmenin sosyal, siyasal, ekonomik ve kültürel alandaki olumlu ve olumsuz yönleri bir arada bulunmaktadır. Küreselleşmenin olumlu etkilerinden biri, yoğun bilgi birikimine girilen bir süreci başlatmış olmasıdır. $\mathrm{Bu}$ yoğunluk, bilgi çeşitliliğini ve zenginliğini hayatın her alanına yaymış, kazanılan bilgiler insanlığın istifadesine sunuldukça gözle görülür bir rahatlama ortaya çıkmıştır. İnsanlar, dünyanın başka bir ucundaki insanlarla anında görüşüp, onlarla her türlü bilgiyi paylaşmayı, ürünlerinden haberdar olmayı ve ticaret yapabilmeyi öğrenirken, bu süreçte gelişimini tamamlamış zengin ülkelerin, zayıf ülkeleri daha da zayıflatacağı endişesini de gün yüzüne çıkarmaktadır.

Küreselleşme bir yandan var olan iş alanlarının bir kısmını ortadan kaldırıp istihdamı olumsuz etkilerken, diğer yandan insanlara yeni iş firsatları yaratmakta, işlerin farklı tarzda yapılma usullerini öğretmektedir. 
İnsan, kendisi dışındaki dünyaları keşfettikçe, başka insanlar ve toplumlar hakkında daha çok bilgi sahibi olmakta, onların bilgi ve birikimlerini kullandıkça hem kendini, hem de yaşadığı toplumu yeniden yapılandırmaktadır. $\mathrm{Bu}$ durum, başka insan ve toplumların öğrenme ve deneyimlerinden yararlanma şansını artırırken, diğer yandan onları dış etkilere daha açık hale getirmektedir.

Yukarıdaki özet bilgilerden de anlaşılacağı üzere küreselleşme, olumlu ve olumsuz bir çok etkiyi bir arada tutmaktadır. İnsanlar ve toplumlar, bir yandan bu sürecin olumlu yönlerini pekiştirip yaygın hale getirirken, diğer yandan olumsuz etkilerini en aza indirerek en yüksek faydayı sağlamaya çalışmalıdır. Burada düzenleyici bir kurum olan eğitime çok iş düşmektedir. Eğitim, halen devam etmekte olan bu sürece, insanları yeniden eğiterek, birey ve toplumları yeni koşullara uyumlu hale getirerek önemli katkılar sağlayabilir.

\section{Bilgi Toplumu}

Bilgi kavramı Latince "informato" kökünden gelmekte, "biçim verme", "biçimlendirme" ve "haber verme" anlamlarında kullanılmaktadır. Bilgi genel anlamda düşünme, yargılama, akıl yürütme, okuma, gözlem ve deney yoluyla elde edilen "düşünsel ürün" ya da "öğrenilen şey" olarak tanımlanmaktadır. Bilgi, bu anlamıyla belirli bir süreçten geçerek işlenmiş, sahibi için anlamlı olan, yönetsel karar almada stratejik öneme haiz olduğu varsayılan veya gerçek değeri olan veri demektir (Öğüt, 2003, 9).

Çağdaş uygarlığın ulaştı̆̆ bilgi düzeyini tanımlamada tam bir görüş birliğine henüz varılmış değilse de, son 20 yıl içerisinde bilim ve teknolojideki baş döndürücü gelişmelerin meydana getirdiği bilgi patlaması ve bilgi teknolojilerinin toplumsal ve ekonomik gelişmeye sundukları olanaklar dikkate alındığında, Toffler'in "üçüncü dalga" olarak betimlediği aşamanın "bilgi çağı", bu dönemin öngördüğü toplumun da "bilgi toplumu" olarak adlandırılması uygun görülmektedir (Özzden, 2002, 15).

Enformatik yüzyıl ya da bilgi çağı, bilginin üretim için temel kaynak olduğu, bilgi üretimi ve iletiminin yaygınlaştığı, bilgi üretimi ve dağıtımında çalışanların çoğunlukta olduğu, sürekli öğrenme ve bilgilenme yoluyla değişme ve gelişmenin kaçınılmaz hale geldiği yeni toplumsal ve ekonomik örgütlenme dönemini işaret etmektedir (Ögüt, 2003, 5). Bilgi çă̆ öğrenmeyi herkes için olanaklı kılan yeni eğitim teknolojilerinin gelişmesine yol açtığı için (Reddi, 1991, 347), "Sanayi Devrimi"nden sonra insanlığın bugüne dek tanık olduğu en önemli olay olarak nitelendirilmektedir. Bir çok akademik yayında, "Enformasyon Devrimi"nin ekonomik, siyasal, toplumsal ve kültürel alanlarda ve ilişkilerde köklü değişimlere yol açacağı ileri sürülmektedir (Kaplan, 1991, 5). 
20. Yüzyılın ortalarında başlayan, özellikle son çeyreğinde yoğunlaşan değişmeler, ekonomik, sosyal, siyasal ve kültürel alanlarda olduğu gibi eğitim alanında da değişmeyi zorunlu kılmaktadır. Bu bağlamda son yıllarda gelişmiş ve gelişmekte olan ülkelerin çoğu, eğitim sistemlerini geliştirmek amacıyla birçok yenilikler yapmıştır. $\mathrm{Bu}$ yenilikler, sistem düzeyinde reformları, modern kurumlar oluşturma çabalarını, modern öğretim araç ve gereçlerin sağlanmasını, öğretmenlerin mesleki bilgi ve beceri düzeylerinin yükseltilmesini ve okul yönetiminde yenilikler yoluyla öğretme-öğrenme sürecini geliştirmeye yönelik değişik politika ve uygulamaları kapsamaktadır (Karip, 1996, 245).

\section{Ĕ̈itim Sürecinde Değişim}

Küreselleşme ve bilgi toplumunun dinamik ve halen devam eden oluşumlar olduğu dikkate alındığında eğitim, eğitimli insan, öğrenme, okul, okul yöneticisi, öğretmen ve öğrenci gibi kavramların yeniden tartışılması gerekmektedir. Küresel çağda eğitim sürecindeki değişimde aşağıdaki hususlar göz önünde bulundurulacaktır ( Özden, 2002, 17):

- Bilgiyi temel alan eğitim programları izlenecektir.

- Çocuklara daha fazla düşünme, tartışma ve araştırma ortamı hazırlanacak; böylece, serbest düşünen, tartışan, araştıran ve bulduklarını değerlendirebilen bir toplum yapısı oluşturulacaktır.

- Yetişkinler eğitim süreci dışında bırakılmayacak; eğitim ve teknolojiye uyumları konusunda sürekli eğitilmeleri gerekecektir.

- Dersler ansiklopedik bilgileri yüklemek yerine, konuları ve olayları derinliğine anlamayı ve eleştirel düşünmeyi esas alacaktır.

- Okullar, öğrencileri gelecek için gerekli bilgiyle yüklemek yerine, okulda verilen bilgilerin yaşam boyu yetmeyeceği görüşünden hareketle öğrenmeyi öğrenmeye geçilecektir.

- Eğitimde sadece sözel ve sayısal zekayı geliştirmek yerine, görsel, kinestetik, ritmik ve benlik gelişimini de içine alan çok yönlü zihin gelişimi hedeflenecektir.

Yeni dönemde eğitimde beceri düzeyinin yükselmesi, bireyin kendini yetiştirmesi, geliştirmesi ve bireysel yeteneklerini sonuna kadar kullanması ön plana çıkacaktır. Bireyin bilgiye odaklı bir yaşamı öğrenme, analitik düşünme, sentez yapabilme, sorunları çözme ve etkili iletişim kurma gibi becerilere sahip olması beklenmektedir. Hızla çoğalan bilgi karşısında, herşeyi bilmek yerine, hangi bilgiyi nereden ve nasıl sağlayacağını bilen, seçici davranan, yani öğrenmeyi öğrenen insana gereksinim duyulacaktır (Numanoğlu, 1999, 333). 
Hemen her birey şu ya da bu biçimde öğrenmeyi bilir. Fakat buradaki asıl önemli konu bilgi çağında ve bilgi yoğun bir toplumda nasıl öğrenmemiz gerektiğidir. Nasıl öğrenmek gerektiğini anlamak, öğrenmenin iç yüzüne vakıf olmaktır. Garavan'a $(1997,24)$ göre de öğrenmeyi öğrenmek, yeni düşünce biçimleri oluşturmak ve davranış değiştirmekle mümkündür. Geleneksel anlamda, belli bilgi stokuna erişmiş insanın yerini, artık bilgi elde etme yöntemlerini bilen insan alacaktır (Özdemir, 2000, 21). A. Toffler'ın “Geleceğin cahili, okuyamayan değil; nasıl öğreneceğini bilmeyen kişi olacaktır" sözü, öğrenme yol ve yöntemlerini bilmenin yeni dönemdeki önemini açıkça ortaya koymaktadır (Boydak, 2001). Bütün bunlar, gelecekte birey ve toplumların şekillenmesinde en belirleyici etkenin bilgi olacağını göstermektedir. Yine A. Toffler'ın, "ilk çağlarda güçlü olan, endüstri çağında zengin olan kazanırdı; bilgi çağında ise bilgili olan kazanacaktır" sözü, önümüzdeki dönemde bireyin, kurumun veya toplumun başarısının bilgiyi üretme ve kullanmadaki etkinliğine bağlı olacağını göstermektedir (Y1lırım, 2001, 3). Sanayi toplumundan bilgi toplumuna geçişte eğitimde yaşanan değişmelere ilişkin özet bilgiler Tablo 1'de verilmektedir.

Tablo 1. Değișen Eğitim Modeli

\begin{tabular}{|c|c|c|}
\hline Ölçütler & Sanayi Toplumu Eğitim Modeli & Bilgi Toplumu Eğitim Modeli \\
\hline Öğretmenin Rolü & $\begin{array}{l}\text { Herşeyi bilen öğretmen, bilgi } \\
\text { aktarıcı, alanında uzman }\end{array}$ & $\begin{array}{l}\text { Yönlendirici, yol gösterici } \\
\text { öğretmen }\end{array}$ \\
\hline Öğrencinin Rolü & $\begin{array}{l}\text { Dinleyici, edilgen, bireysel } \\
\text { çalışma }\end{array}$ & $\begin{array}{l}\text { Aktif, işbirliğine dayalı takım } \\
\text { çalışması }\end{array}$ \\
\hline Yöneticinin Rolü & Yönetim lideri & Öğretim-yönetim lideri \\
\hline Öğrenme Yöntemi & Sınıfta öğrenme & Kişisel araştırma \\
\hline Öğrenme Şekli & Bireysel çalışmayla öğrenme & Takım çalışmasıyla öğrenme \\
\hline Eğitim Programları & Standart eğitim programları & Değişken eğitim programları \\
\hline İşgören Geliştirme & Hizmet-içi eğitim & Örgütsel öğrenme \\
\hline Başarı Ölçütü & $\begin{array}{l}\text { Ezberlenmiş bilgi aktarımının } \\
\text { esas alınması }\end{array}$ & $\begin{array}{l}\text { Kavramları çok boyutlu olarak } \\
\text { tanımlayabilme }\end{array}$ \\
\hline
\end{tabular}

Kaynak: (Aytaç, 1999, 75; Aktaran, Nartgün, 2002, 132).

Tablo 1'de görüldüğü gibi sanayi toplumundan bilgi toplumuna geçişte eğitim modelleri önemli değişiklikler göstermektedir. Buna göre bilgi toplumuna geçişte, yol gösterici öğretmen, takım çalışmasıyla öğrenen öğrenci, öğretim-yönetim liderliğine dayalı yöneticilik, kişisel araştırmaya dayalı öğrenme yöntemi, değişken eğitim programları, örgütsel öğrenme ve çok boyutlu kavramsal öğrenme ölçütü önemli hale gelmektedir. 


\section{Bilgi Toplumunda Okul}

Her dönemde eğitim sistemi, okul yoluyla toplumun kültür mirasının aktarılması, çocuğun toplumsallaşması, topluma birlik ve dayanışma ruhu verme, yenilikçi ve değişmeyi sağlayıcı eleman yetiştirme gibi işlevleri yerine getirmiştir. Bunu başarabilmek için eğitimin kendisini yeniliğe taşıması, okulun da bu süreçte düzenleyici ve uyumlayıcı bir kurum olması gerekmiştir (Tezcan, 1992, 48-51).

Okulun işlevleri sadece bunlarla sınırlı değildir. Ekonomik işlev önceki dönemlerde olduğu gibi bugün de okulun önemli işlevlerinden biri olarak öne çıkmaktadır. Ekonomik gereksinmeler insan kaynaklarının etkili kullanımını ve tüm gençliğin iş yaşamına hazır hale getirilmesini zorunlu kılmaktadır. Bilgi-teknoloji yoğun bir toplumda yaşayabilmek, daha iyi çalışma olanaklarına kavuşmak yeni dönemde gençliğin en önemli hedefleri arasında yer alacaktır. Eğitilmiş genç nüfusa bu olanakları sunma işlevi okullara yüklenmiş durumdadır. Çevrede meydana gelen değişikliklere duyarlı, gerekli kararları hızlı ve doğru biçimde alabilen, değişimin gereklerini en kısa zamanda programlara yansitabilen bir okul kimliği geliştirmek temel ihtiyaç haline gelmiştir (Doğan, 1997, 7, 13-14). İşe girmede aranan koşulların gittikçe daha özel ve uzmanlık gerektirecek bilgi ve becerilere dayanması, okulun görevlerinin çeşitlenerek artmasını, okuldaki eğitimin gelişen ve değişen teknolojiye ayak uyduracak biçimde daha sistemli, açık ve kesintisiz yapılmasını zorunlu hale getirmiştir (Tan ve diğerleri, 2002, 8).

Bilgi toplumunda okula duyulan gereksinim göreceli olarak azalmış, öğrenme okul sınırlarının dışına taşmış, daha hızlı ve keyifli hale gelmiş olmakla birlikte bu durum, okulun bilgi üretmedeki önemini azaltmamış; tam tersine okulun bu konudaki önemi daha da artmıştır. Çünkü bilgi toplumunda bilgi hem daha yoğun, hem de nitelik olarak daha karmaşık hale gelmiştir. Bilginin yoğun ve karmaşı olması onu alıp kullanacak bireylere sınırlılık yaratmaktadır. Okul bu süreçte bireyleri daha bilinçli ve seçici olmaya yönelterek, öğrenmenin yol ve yöntemlerini keşfetmelerini sağlayarak ve bilgiye ulaşma yollarını daha sistemli hale getirerek onlara daha geniş bir hareket alanı yaratabilir.

Yenilikler, okul ve öğrenme ortamlarının yapısında değişimi zorunlu kılmaktadır. Eğitim kurumları olarak okullar, sürekli yeniliğe açık, bilginin üretildiği, kullanıldığı ve geliştirildiği, takım çalışması ile insana güven sağlayan, günün her saatinde kullanıma açık, toplumun yeni bilgi ihtiyaçlarının karşılandığı, öğrencide özgün ve yaratıcı düşünceyi geliştirmeyi amaçlayan çok işlevli bir yapıda olmak zorundadır. Yeni okul kültüründe en belirgin özellik, takım halinde çalışma ve öğrenmedir. Bireylerin sürekli öğrenme arzusu içinde olmaları, yüksek motivasyon ve 
yükssek performansla çalışmaları takım halinde öğrenme ve başarının ön koşullarıdır (Numanoğlu, 1999, 345).

Bugün artık çok sayıda okulun yeni reformların gerektirdiği öğrenme türünü üretemediği ileri sürülmektedir. Gerekli öğrenmeyi üretememe, okulların bunu istememelerinden çok, onu nasıl yapacaklarını bilememelerinden kaynaklanmaktadır. $\mathrm{Bu}$ yüzden okulların yeniden yapılandırılmasına duyulan gereksinim giderek artmaktadır. Bu, okulun hem öğrenci hem de öğretmen için gerçek anlamda bir "öğrenen okul" olması demektir (Leithwood ve diğerleri 1998, 243-244). Öğrenen okul düşüncesi güç ve otoritenin tek elde toplanmadığı, okula ilişkin karar alma yetkisinin başta okul yöneticileri ve öğretmenler olmak üzere, aileler, öğrenciler ve toplum üyeleri arasında dengeli dağıtıldığı bir süreçle yaratılabilir. $\mathrm{Bu}$ süreçte ayrıca standartlaştırılmış uyum yerine, farklılıklar desteklenir ve etkili biçimde yönetilir (Oswald, 1997, 181-184)

Öte yandan Senge (1990), bugünkü işleyişleri ile okulların öğrenen örgütler olmadıklarını ileri sürmektedir. Ona göre okulların aşırı kurallı olmaları, öğretim sürecinde bu aşırı kurallılığa uymak zorunda kalmaları, yöneticilerin işbirliğiyle çalışmaya alışkın olmaması, açık ve birleştirici bir vizyondan yoksunluk ve okul etkinliklerinin birbirinden kopuk biçimde yürütülmesi, okulların, öğrenen örgüt olmaları önündeki önemli engeller olarak görünmektedir. Ona göre mevcut işleyişte okul kavramı, girişimcilik ruhu ve ileri görüşlülükten çok, emirlerin yerine getirilmesini çağrıştırmaktadır (Morrison 1998, 166).

\section{Bilgi Toplumunda Eğitim Programları}

Bilgi toplumunda eğitim anlayıșı, eğitim kurumlarında öğrencilerde gözlenen ilgi ve yetenek farklılıklarına cevap veren ve kendi içinde çeşitliliğe gidebilen esnek programlar uygulanmasını gerektirmektedir. Programda ortak zorunlu derslerin yanısıra, öğrencilerin ilgi, yetenek ve ihtiyaçlarına cevap veren seçmeli derslerin bulunması, her öğrenci grubu için ayrı programların yapılmasını gerektirmektedir (Kuzgun ve diğerleri, 1997, 28). Eğitim programlarının dar kapsamlı becerilerden, üretken ve geniş kapsamlı bilgi ve becerilere doğru yönlendirilmesi gerekmektedir (Doğan, 1997, 18). Alışılmış biçimiyle okuldaki öğretim, çoğunlukla bir dizi bilginin öğrenciye aktarılması ve bunların ezberlenmesi ile sınırlı kalmaktadır. Program, öğrencilerin düşünme ve problem çözme yeteneklerini geliştirici içerik taşımamaktadır. Düşünme yeteneği gelişmeyen bir öğrencinin en büyük zihinsel etkinliği, depoladığı bilgiyi geri çağırmak, ancak bu bilgiyi nasıl ve nerede kullanacağını bilememekten ibaret olacaktır (Özden, 2002, 18-19). Oysa bilgi çağında "bilgili" olmanın anlamı, öğrenme kapasitesini geliştirmek, bilgiyi kullanabilmek, yeni beceriler kazanmak ve bunu sürekli bir davranışa dönüştürmektir (Yıldırım, 2001, 6). Kazanılan beceriler birey ve toplumun her alandaki gereksinmelerine cevap vermelidir. $\mathrm{Bu}$ beceriler 
bir yandan birey ve toplum arasındaki ilişkileri düzenleyerek uyumlu hale getirmeli, diğer yandan bireyin başta kendisi olmak üzere tüm toplum ve evrenle barışık yaşaması için gerekli sosyal-kültürel ve psikolojik yeterlilikleri kazandırmalıdır.

Öte yandan iş yaşamında aranan becerileri kazandıracak eğitim hizmetinin tüm öğrencilere sunulması için, farklı program düzenlemeleri ve yöntemlerinin uygulamaya konulması da bir başka gerekliliktir. Bunun için öğretimde yer, zaman ve yöntem kısıtlamalarının ortadan kaldırılması gerekmektedir (Doğan, 1997, 19). Bu süreçte öğrenciyi, aktif biçimde problem çözen biri olarak değerlendiren Bruner de, yeni öğrenme-öğretme sürecini, öğrencinin, yönetilebilir veya çözülebilir problemleri keşfetmesine yardım eden bir süreç olarak ele almaktadır (Wood, 1998, 168).

$\mathrm{Bu}$ süreç her öğrenci için aynı değildir. Öğrenme, bilgiyi işleme ve problem çözme gibi düşünsel etkinliklerde insanların farklı yöntemler kullandığı artık kabul gören bir gerçektir. Kolb'a (1984) göre, olaylara değişik açılardan bakan, problemleri farklı yaklaşımlar kullanarak çözen insanların öğrenmeleri de farklılık gösterecektir. Ona göre bazı insanlar duyumsayarak ve özümleme yoluyla öğrenirken, diğer bazıları da olay ve olguları soyut olarak, kendisi ile ilişkilendirmeden, mantıksal bir süzgeçten geçirerek öğrenir. Yine bir grup insan, eşya ve olguları izleyerek, tefekkür halinde, yavaş bir süreç içerisinde ve belli bir perspektiften süzerek öğrenirken, diğer bir grup da yeni bilgileri hemen denemek ve yaparak öğrenmeyi tercih eder (Özden, 2000, 76).

Görüldüğü gibi farklı düşünme biçemlerine sahip öğrencilerin, öğrenmelerinin de farklı olduğu görüşü eğitimde ilgi odağını öğrenciye kaydırmıştır. Bu değişimde demokratik tutum ve alışkanlıkların gelişmesi de önemli rol oynamıştır. Kepenekçi-Karaman'a $(2003$, 45) göre demokratik eğitimde eğitimin merkezinde birey, yani öğrenci vardır. Her birey kendine özgü bir kişilik olarak kabul edilir ve ona saygı duyulur. Böyle bir eğitimde öğrenmenin yükü daha aktif olan öğrenci üzerinde iken; öğretmen, öğrenmeyi kolaylaştıran kişi rolündedir.

Diğer yandan öğrenci, yeni süreçte dar ve sınırlı düşünen öğrenci tipinden çıkıp, mevcut bilgilerden başka bir yere ulaşabilen, keşfeden ve eldeki bilgilerin ötesine gitmeyi hedefleyen "entelektüel öğrenci" tipine kavuşmalıdır. Bu durum, tek halkalı (döngülü) ögrenmeden çift halkalı (döngülü) ögrrenmeye geçmeyi gerektirir. Tek halkalı (döngülü) öğrenme, bir kişinin bir işi tamamlaması, mevcut yöntemleri işe uygulayabilmesi için gerekli öğrenmedir (Bennett, 1999, 118). Tek halkalı (döngülü) öğrenmeye eğilimli kişiler uyarıcı davranışları ihmal ederler. Bu kişiler, çevresel değişmelere kısmi bakış yönelterek, sorunlara genellikle sınırlı biçimde, tek düzeyde ve mekanik eylemlerle tepki verirler. Zoraki uyum, riskten kaçınma ve rutin davranışlar bu bireyler için yaklaşım zenginliğini, denemeyi ve risk 
almayı engeller. Tek halkalı (döngülü) öğrenmeye sahip kişiler öğrenirler, fakat bunu, dar biçimde tanımlanacak ölçüler içinde gerçekleştirirler. $\mathrm{Bu}$ öğrenme türü çevre, göreceli olarak durağan kaldığ 1 sürece sürdürülebilir. Ancak, çevre dinamik ve hareketli hale geldiğinde çift halkalı (döngülü) öğrenmeye geçmek kaçınılmazdır (McGill ve diğerleri, 1992, 6). Çift halkalı (döngülü) öğrenmede bireyler, tek halkalı (döngülü) öğrenmenin işleyiş sürecinde baskın şekilde var olan varsayım ve koşulların nasıl değiştirilebileceğini öğrenirler. Bu öğrenme düzeyi, mevcut durumun köklü biçimde farklılaştığı dönüşümcü bir değişmeye yol açar (Argyris ve Schön, 1996, 21). Senge'nin "yaratıcı öğrenme" olarak adlandırdığı bu öğrenme türünde birey, sürekli deneyim ve araştırma dönütlerine bağlı olarak problemlerini tanımlayarak çözüme kavuşturur (Bennett, 1999, 118).

\section{Bilgi Toplumunda Okul Yöneticileri}

Bilgi toplumunda eğitimde yaşanan değişim okul yöneticilerinden beklentileri de değiştirmiştir. Bu değişim küresel ölçekte yaşanan çok yönlü değişimin bir sonucudur. John Naisbitt, geniş sosyal, politik, ekonomik ve teknolojik değişmeleri anlatmada "megatrend" kavramını kullanmıştır. Ona göre 1980'lerde başlayan büyük değişim, insan ve toplumları oldukça farklı evrelere taşımıştır. Bu değişim Tablo 2'de özet olarak sunulmuştur. Buna göre büyük değişim,

Tablo 2. Mega Eğilimler ve Yönetici Rolleri

\begin{tabular}{|l|l|}
\hline$\bullet$ Endüstriyel toplumdan & $\bullet$ Bilgi toplumuna \\
\hline$\bullet$ Zorlama teknolojiden & $\bullet$ İnsan yönelimli yüksek teknolojiye \\
\hline$\bullet$ Ulusal ekonomiden & $\bullet$ Dünya ekonomisine katılmaya \\
\hline$\bullet$ Kısa dönemlilikten & $\bullet$ Uzun dönemliliğe ilgi duymaya \\
\hline$\bullet$ Merkeziyetçilikten & $\bullet$ Yerinden yönetimciliğe \\
\hline$\bullet$ Kurumsal yardımdan & $\bullet$ Kendine yardıma \\
\hline$\bullet$ Temsili demokrasiden & $\bullet$ Katılımcı demokrasiye \\
\hline$\bullet$ Hiyerarjik iletişim ve kontrolden & $\bullet$ Ağlara \\
\hline$\bullet$ Gelişmiş ülkelerin ilgi ve çabalarından & $\bullet$ Gelişen ülkelerin ilgi ve çabalarına ilgiye \\
\hline$\bullet$ Ya "o ya şu” düşüncesinden & $\bullet$ Çoklu seçme seçeneklerine doğru \\
gerçekleşmiştir.
\end{tabular}

Kaynak: Balc1 $(2001,114)$.

Tablo 2'de görüldüğü gibi son 25 y1lda yaşanan büyük değişim, insan ve toplumları daha esnek, daha çeşitli, daha geniş düşünen, dünyaya daha açık ve hareket serbestliği daha fazla olan bir döneme getirmiştir. Yukarıda 
özetlenen mega eğilimler çerçevesinde okul yöneticilerinden aşağıdaki önemli roller beklenmektedir. Buna göre okul yöneticisi (Balc1, 2001, 114):

- Yüksek düzeyde stratejik planlama kapasitesine sahip olmalı, olay ve ilişkilerin ardındaki büyük resmi görebilmelidir.

- Yüksek düzeyde pazarlama yeteneğine sahip olmalıdır.

- Okullara yeni pazarlama ilgileri yaratmalı ve yeniden yapılaşmış kamu fon kaynağı sağlamalıdır.

- Okulların, geniş bir öğrenci kesiminin ve toplumun ihtiyaçlarını karşılayabilecek program ve hizmetler sunabilmesini sağlamalıdır.

- Okulların, hayat boyu eğitimin bir parçası olmasını sağlamalıdır.

- Okulların, okul destek hizmetleri dağıtımının merkezi olmasını sağlamalıdır.

- Ulusal program çerçevelerinin, okulun özerk yapısını her koşulda azaltmadığının bilincinde olmalıdır.

- Toplumun, okullarının karar alma süreçlerine, geçmişe göre daha aktif bir katılım göstermelerini sağlamalıdır.

- Okulların amaç ve ürünlerine daha çok vurgu yapılacağını bilmeli, eğitim düzeyi oldukça yüksek bir toplumda öğrencilere en iyiyi sunmanın toplumun temel söylemi ve ilgisi haline geleceğini unutmamalıdır.

Kaliteyi artırma ve hizmetleri yaygınlaştırmaya dönük artan talepler beraberinde yeni okul yöneticiliğini öne çıkarmıştır. Okul yöneticileri artık okul liderleri olmak ve daha fazla inisiyatif almak zorundadırlar. Sistem, onlara bu yeterlilikleri kazandıracak mesleki gelişme ve yetişme olanakları sunmalı, onların hata yapmaya dayalı öğrenmelerini bir dereceye kadar hoş karşılamalıdır.

Okul yöneticilerinin değişimi anlayabilmeleri ve yönetebilmeleri gerekmektedir. Etkili değişimi yakalayabilmeleri için de dönüşümcü liderliğin aktif rolüne uyum sağlamaları gerekmektedir. Okul yöneticisi, çalışanlarını motive etmeli, destekleyici bir kültür yaratmalı, ortak grup vizyonu geliştirmeli, etkin eğitim programları geliştirmeli, olumlu bir öğrenme çevresi oluşturmalı, yüksek performansa özendirmeli ve sonuçlardan öncelikle sorumlu biri olarak insan kaynaklarını en etkili biçimde kullanabilmelidir (Smith ve Pıele, 1997, 3-4). Çok kültürlü bir yapıda hiyerarşik karar alma yerine, okul yöneticilerinin, çeşitli birey ve gruplara danışarak fikir birliğine ulaşmaları beklenmektedir. Stratejik planlama ve bireyin kendi değişimine ilişkin gündemi hazırlama kapasitesi önemli hale gelmiştir. Böylesine yüksek değişim hızının yaşandığı bir ortamda okul yöneticiliği hem zor hem de karmaşık bir uğraştır (Balcı, 2001, $115)$. 
Okul yöneticisi, değişime direnme yerine, yeni durumla gelen firsatları görerek, koşulların gerektirdiği değişim ve yenileşmeyi kolaylaştırmalıdır. Bilgiyi yönetme, sezgiyi kullanma, ikna etme ve sürekli öğrenme becerilerine sahip olmak okul yöneticisinin diğer önemli özellikleri arasında yer almaktadır (Numanoğlu, 1999, 345). Okul yöneticisinin imaj1 1980'lerden bu yana "kapı bekçisi” olmaktan, "öğretim lideri” olmaya doğru değişim göstermiştir (Balc1, 2001, 116). Yöneticilik artık otorite ve güç kullanmaktan çok, disiplinli çalışmak ve sorumluluk üstlenme mesleğidir (Özden, 2002, 8-9).

Bugün eğitimde gelinen nokta bize tepkisel değil, sezgisel davranmanın önemini kavratmıştır. Problem ortaya çıkıp, bütün sonuçlarını gösterdikten sonra değil, daha meydana gelmeden çeşitli belirtilerden onun gelişini kestirebilmek önemli hale gelmiştir. Okul yöneticisi, hareketli bir çevre ve yüksek değişim ortamında, amaçları kontrol edebilen, güçlü sezgiye sahip olan kişi olarak öne çıkmalıdır (Biçer, 1999, 94-95).

Yeni süreçte okul yöneticilerinden, çalışanlarını belli hedefler doğrultusunda harekete geçirmeleri beklenmektedir. Liderliğin ön koşullarından biri, insanları heyecanlandıracak ortak ve paylaşılan bir vizyon etrafinda toplamak ve bu vizyonu hayata geçirebilecek stratejileri geliştirmektir (Limerick ve diğerleri, 1994, 38). Artık okul yöneticisinin rollerinin, dar anlamda belli yeniliklerin uygulanmasını etkilemekten, okulda değişmeye liderlik etmeye doğru değiştiği görülmektedir. $\mathrm{Bu}$, bir anlamda yönetim ve liderliğin farkıdır. Liderlik, misyon, güç işe odaklanma; yönetim ise planları desenleyip gerçekleştirmek, işleri yaptırmak ve insanlarla etkili biçimde çalışmaktır. Liderlik, bir vizyonu aktarma, ortak sahipliği başarma ve gelişimci planlama ile ilgilenirken; yönetici, kaynak sorunları ile ilgilenir ve eşgüdümlü çalışma için çaba harcar (Balc1, 2001, 116).

Değişim sürecinde okul liderleri, vizyon geliştirme ve bunu herkesle paylaşma görev ve sorumluluğu üstlenecektir. Vizyonun en değerli yararlarından biri bir mıknatıs gibi hareket etmesidir; o, insanları çeker ve bir araya getirir (Maxwell, 1999, 164). Vizyon, gelecekte ulaşmayı çok istediğimiz bir durumun, varmak istediğimiz noktanın resmidir. Vizyon, birlikte geleceğin resmini çizmek ve resmin birlikte çizildiğini hissettirmektir. $\mathrm{O}$ güçlü bir gelecek duygusudur. Bugünün olanaklarını aşarken, aynı zamanda bugünü yarına bağlayan entelektüel bir köprü, geçmişi haklı çıkarmak için değil, geleceğe bakmak için oluşturulan bir temeldir (Aytaç, 2003, 2). Marshall Sashkin de, vizyon sahibi liderlerin birlikte çalışmayı olanaklı kılan kapsamlı bir davranış repertuarına sahip olduklarını; bu liderlerin, temel konulara odaklanarak, etkili iletişim kurarak, değişime uyum sağlayarak, kendilerine ve başka insanlara dönük saygılarını geliştirerek ve makul/ölçülü riskler alarak okul vizyonunun gerçekleşmesini sağlayan bir çevre yarattıklarını ileri sürmektedir (Lashway, 1997, 135). 


\section{Bilgi Toplumunda Öğretmen}

Küreselleşen bilgi toplumunda değişim sürecinin doğurabileceği muhtemel sonuçlara karşı önlem almak, insanı ve toplumu değişimle baş edebilecek şekilde gelecek için hazırlamak önemli hale gelmiştir. O halde bu sürece hazırlık, eğitim kurumları ve bu kurumlarda görev yapacak öğretmenlerden başlanmalıdır. Bireyin hızla değişen bilgi toplumuna katılımı ve bu süreçte hak ettiği yeri alması, yeni bilgiler kazanması, becerilerini zenginleştirmesi, yaşam boyu öğrenme ve eskisine oranla daha çok nitelikli olmayla başarılabilir (Yurdabakan, 2002, 63).

Bilgi toplumunun yarattığ 1 okul kültüründe öğretmenlerin yeni roller ve görevler üstlenmesi bir zorunluluk halini alacaktır. Öğretmen, çok hızlı bilgi üretimi karşısında sürekli olarak bilgilerini güncellemek zorundadır. Bilgi toplumunun eğitimcisi olan öğretmenler, bilginin eğitimsel değerinin farkında olacak, ona ulaşma konusunda da etkili bir rehberlik ortaya koyacaklardır (Numanoğlu, 1999, 346). Bunun için öğretmenlerin bundan sonraki süreçte daha değişik ve yeni yeterliliklerle yetiştirilmeleri gerekmektedir. Öğretmenlerin değiş̧ik kültürlerden gelen, sosyal yönden zayıf öğrencilerin öğrenmelerini gerçekleştirebilen, mevcut çatışmaları barışçıl yollarla çözebilen, kişilerin kimliklerine ve kültürlerine saygı duyan, toplumsal sorumluluk taşıyan yurttaşlar olarak yetişmeleri, bunun için gerekli bilgi, beceri ve değerlerle donanmış olmaları arzulanmaktadır (Yurdabakan, 2002, 64).

Mevcut sistem öğretmeni temel bilgi kaynağ durumda öğretmen, büyük ölçüde anlatan ve aktaran konumunda iken, öğrenci de sadece kendisine aktarılanı alan pasif bir konumda bulunmaktadır. $\mathrm{Bu}$ yaklaşım, öğrencideki girişimci ruhu köreltmekte; öğrenci, kendi kendine öğrenme becerisi geliştirememekte ve eğitim sürecinde yetenekleri doğrultusunda ilerlemesine olanak tanınmamaktadır (Doğan, 1997, 9).

Bilgi toplumunda öğretmenin temel rolü, öğrenme ortamının merkezine öğrenciyi alarak, bilgiye nasıl ulaşılacağını ve bundan nasıl yararlanılacağını uygun ortamlar hazırlayarak öğretmektir. Bilginin seçimi konusunda uzman olan öğretmenler, temel bilgiyi öğrenciye kazandırabilmelidir. Bu da öğrenci için öğrenmeyi öğrenmek anlamına gelir. Ancak burada öğretmen, öncelikle öğrencisini iyi tanımalı, onun öğrenme düzeyine uygun öğrenme imkânları sunmal1, öğrenmeyi öğrencisine kolaylaştırarak, onu doğru yönde yönlendirmelidir (Numanoğlu, 1999, 347).

\section{Bilgi Toplumunda Öğrenci}

Küresel bilgi toplumunda eğitimsel değişim, yeni döneme uyum sağlayabilen öğrencilerin yetiştirilmesini, bunun için eğitim programlarında değişikliğe gitmenin gereğini ifade eder. Bu bağlamda daha okul yıllarında 
küresel düşünen öğrenciler yetiştirilir. Küresel düzeyde sorumluluk üstlenen ve tutum oluşturan gençlik yetiştirmek amaçlanır. Bu gençlik, küresel düzeyde en uygun duruşu sergilerken, aynı zamanda yerel gerekleri de göz ard1 etmeyen bir gençliktir (Tezcan, 2002, 57). Küresel eğitim uygulamalarında, yaşanabilir bir gelecek oluşturmak için tüm temel stratejik öğeleri sunma, uzlaşmayı sağlama, kaderciliği ve ilgisizliği ortadan kaldırma vardır. Ayrıca değişimci ve barışçıl bir dünya yaratmak için ortak tutkuları olan, dünyaya açık, kendine güvenen, eşitliği savunan, kültürel ve tinsel zenginliğe önem veren öğrencilerin yetiştirilmesi amaçlanır (Doğan, 2002, 90).

Ülkeler içinde ve ülkeler arasında eşitsizlikleri ve dengesizlikleri besleyen süreçler dur durak bilmezken, bireylerin ve toplumların daha iyi, daha insancıl ve daha barışçıl bir geleceğe doğru nasıl yol alacakları ve bunu nasıl başaracakları bir başka tartışma konusudur. Rekabet ve işbirliği kavramları bu süreçte en fazla öne çıkacak kavramlar olarak görünmektedir.

Ekonomik küreselleşme ile yakından ilişkili bir kavram olan rekabet, artık üniversitelerin de dünyasına girmiştir. $\mathrm{Bu}$ bağlamda gelişmiş ülkelerdeki üniversitelerin küresel rekabet çerçevesinde uluslararası öğrenci ve araştırmacı kitlesini çekme çabaları yaygınlık kazanmaktadır. Gelişmiş ülkelerdeki bir çok üniversite, uluslararasılaşmayı önemli misyonlarından biri saymıştır. UNESCO verilerine göre, 1995 yilında ev sahibi 50 ülkede yükseköğretime kayıtlı 1,5 milyon yabancı öğrenci bulunmaktadır. Az gelişmiş ülkelerden gelen 800000 'den fazla öğrenci, öğrenim görmek üzere bir başka ülkenin yükseköğretim sistemine kayıt yaptırmıştır (Kurul Tural, 2004, 95).

Eğitim alanında ülkeler arasında ortak anlayışlar geliştirmek amacıyla işbirliğiyle uygulamaya konan öğrenci değişimi projesi de bu çabalar arasında yer almaktadır. Yakın zaman öncesinde Avrupa ülkeleri arasında başlatılan ve şu anda ülkemizin de üye olduğu Avrupa TopluluğuERASMUS eğitim projesi kapsamında öğrenci değişimi yapılmaktadır. Bu projeye göre öğrenciler, öğrenimlerine ara vermeden bir sömestrde istedikleri üniversitelerden dersler alabilmekte, bir başka sömestrde başka ülkeleri seçebilmektedirler. Böylece öğrenciler, değişik kültürleri tanıma, farklı görüş ve düşüncelerden istifade etme şansı yakalamaktadırlar. Söz konusu bu proje ile milyonlarca öğrenci, ülkeler arasında rotasyona tabi tutulacak, böylece ülkeler arasında bütünleşmenin temelleri atılacaktır (Tezcan, 2002, 58).

Küreselleşmenin eğitimsel amaçları ve eğitim sistemlerini nasıl etkilediğine iyi bir örnek İngiltere'dir. Verilere göre çeşitli ülkelerden İngiltere'ye öğrenci akışı giderek artma eğilimi göstermektedir. 1995-1996 eğitim-öğretim yılında İngiltere'de 196,346 öğrenci kendi ülkelerinin kamu yönetimlerince finanse edilmişlerdir. Aynı yıl İngiltere'de öğrenim gören 
öğrencilerin \%43'ü Avrupa Topluluğu ülkelerinden, \%6's1 diğer Avrupa ülkelerinden, \%7'si Afrika'dan, \%29'u Asya'dan, \%1'i Avustralya'dan, \%5'i Orta Doğu'dan, \%7'si Kuzey Amerika'dan, \%1'i ise Güney Amerika'dan gelmişlerdir (Kurul Tural, 2004, 97).

Yeni süreçte öğrenci, eski dar kalıplardan çıkıp, öğretmenin rehberliğinde öğrenmeyi öğrenen birey konumuna gelecektir (Numanoğlu, 1999, 347). Öğretimin ilk basamağından son basamağına kadar öğrenciler, problemi belirleme, olası çözüm önerileri geliştirme, mevcut çözüm önerileri içinde en makul olanı tespit edip uygulama ve elde edilen sonucu temel amaçlarla karşılaştırarak gerekli düzeltmeleri yapma becerileriyle tanıştırılacaktır. Gençler, ancak bu yolla bilgiyi anlayan, yorumlayan ve geliştirebilen özelliklere sahip olarak yetiştirilebilirler (Doğan, 1997, 18). Böyle bir sistemde yetişen öğrencilerin fikirleri analiz ve sentez etmeleri, anladıklarını başkalarıyla sözlü ve yazılı olarak paylaşmaları, öğrendiklerini sağlam bir çerçeveye oturtmaları, konuyu öğrenerek soruları yanıtlamaları ve günlük yaşamla ilişki kurmaları sağlanacaktır (Tan ve diğerleri, 2002, 9)

Bilgi toplumunun öğrencileri, teknolojinin imkânlarından yararlanarak projeler üretebilen, farklı proje gruplarında çalışabilen, ekiple çalışma becerisine sahip, bağımsız düşünebilen, hayal gücü yüksek, mantıklı kararlar alabilen, aktif katılımc1, bilgiyi arayan, düşünen, üretken, önyargisız ve her türlü düşünceye saygılı bireyler olacaklardır (Numanoğlu, 1999, 348).

\section{SONUÇ}

Çağdaş dünya sosyal, siyasal, ekonomik ve kültürel alanlardaki ani ve hızlı değişim süreci ile tanımlanmaya başlanmıştır. Bilginin küresel düzeyde yayılması bilgiye dayalı ekonomik bir süreci başlatmış, bu süreç gelişmiş ülkelere üstünlükler sağlarken, gelişmesini henüz tamamlamamış ülkeler için de çeşitli engeller yaratmıştır. İnsanlar ve toplumlar bir kez daha tarihin önemli dönemeçlerinden birini yaşamaktadır. Hemen herkes ne zaman, ne olacağını kestiremese de niçin öyle olduğunu anlamış görünmektedir. Büyük değişimin temelinde, bir yanda sistemli araştırma ve geliştirme çabaları, diğer yanda bilgi sektörünün istihdamdaki payının giderek artması yatmaktadır. Örneğin bugün, bilgisayar teknolojisinin bir sonucu olarak Amerika'daki işgücünün yaklaşık \% 45'i bilgi işleme alanında, \% 25'i hizmet sektöründe, diğer \% 25'i de sanayide çalışmaktadır (Web ve diğerleri 1992, 569). Görüldüğü gibi imalat sanayisine dayalı bir ekonomiden hizmet ve bilgi teknolojisine dayalı bir ekonomik yapıya doğru bir değişim yaşanmaktadır. Bu gelişmede insanoğlu ve zekasının bitip tükenmeyen potansiyeli ve yaratıcılığını da unutmamak gerekir. İnsanoğlunun yaratıcı zekası ile başlayan bu zor ve sancilı süreç, yine onun zekasıyla inşa edilecektir. H. G. Wells'in dediği gibi "insanlık tarihi, eğitim ve felaketin yarışı tarihidir" (Slaus ve diğerleri, 2004, 479). 
Eğitimin her toplumda özel bir önemi olmuştur. Eğitim bir yandan geçmişe bakmayı, ama ona takılmamayı, diğer yandan geleceğe bakarak, insanın yaratıcılığını keyifli bir arayış ve gezintiye çıkarır. Bu anlamda eğitim, insan ve toplum için bir yeniden inşa aracıdır. Dünya döndükçe insandaki merak ve öğrenme isteği bitmeyeceğine göre, insan ve toplumun kendini yeniden üretmesinde eğitime çok iş düşecektir. İnsanlık hızla yürüdüğü kaygan zeminde düşmeden yürümeyi, bunu başarabilmek için de sürekli değişen yol haritasını güncellemeyi öğrenmelidir.

Dünyamız değişik insanlar, farklı sosyal ve kültürel gereksinmeler, yeni yaşam tarzları ve farklı alışkanlıkları ile giderek çeşitlenen ve farklılaşan bir yaşama doğru kaymaktadır. Giderek farklılaşan ve dağılma eğilimi gösteren toplumsal çevrenin bütünlüğünü koruma ve sürdürme sorunu ortaya çıkmaktadır. Balcı'nın $(1995,114)$ belirttiği gibi çevre ne denli belirsiz ve kestirilemezse o ölçüde farklılaşma ve bütünleşme gereklidir. Ancak bütünleşme ve farklılaşma ters işleyen süreçlerdir. Yani farklılaşma ne denli fazlaysa bütünlüğü sağlamak da o denli zor olmaktadır.

Kültürel açıdan bakıldığında da küreselleşme iki zıt olguyu bir arada tutmaktadır. Bir yandan giderek farklılaşan bir dünya, öte yandan bu farklılaşma ya da dağılma eğilimini dizginlemeye çalışan standardizasyon çabaları. Bir yandan toplumların yaşam biçimleri artan oranda birbirine benzer hale gelirken, diğer yandan farklılaşma ile toplumun çoklu kimlikleri ve özellikleri öne çıkmaktadır. Böylece küreselin içinde yerelin daha fazla üretimi yapılırken, aynı zamanda bu "çoklu yüzlerin" benzeştirilmesi çabası devam etmektedir (Kurul Tural, 2004, 66). Bu iki zit olguyu dengelemek, öncelikle toplumun uyumlayıcı bir kurumu olan eğitime düşmektedir. Eğitim programları insan ve toplumların birbirlerini daha fazla tanımaları ve birbirleri hakkında daha çok şey öğrenmelerini sağlayacak biçimde yeniden düzenlenmelidir. Birbirini tanıma arttıkça, zamanla "biz" ve "onlar" arası ayırımın azalacağı söylenebilir. Ne var ki fiziksel mesafeler kapansa ve insanlar bedenen bir araya gelse dahi, ruhen birbirlerine yabancılaşacakları düşüncesi ağır basmaktadır. Bu durum, insanların birbirlerine araçsal yolla bağlanmaları demektir. İnsanlar, dünyanın her yerinde farklılıklarıyla birlikte bir arada yaşamanın asgari koşullarını belki bulacak ve belki de bütünlük bir ölçüde sağlanmaya çalışılacaktır. Ancak insanlar arası ilişkilerin giderek daha mekanik bir hal alacağ 1 tahmin edilmektedir. Bu sakıncayı bir ölçüde gidermek, insanların ruhsal, duygusal ve benlik zekalarının güçlendirilmesini gerektirecektir. $\mathrm{Bu}$ yüzden söz konusu alanlara gelecekte daha çok yer verilmesi, eğitimin gereklerinden biri olabilecektir.

Nüfusun çeşitlenmesi, özellikle eğitim alanında görev yapanların çok kültürlü ve farklı sosyo-ekonomik geçmişten gelenlerin eğitimi konusunda bilgili ve deneyimli olmaların gerektirecektir.Yeni disiplinler aras1 yaklaşımla dünya tarihi, kültürleri ve coğrafyası küresel bir perspektifle 
yeniden öğretilecek; bilgi akışı, serbest dolaşım ve öğrenci değişimi arttıkça kişilerin diğer kültürleri öğrenme ve anlama istekleri artacaktır. Eğitim politikaları farklı kültürel ve dinsel altyapıyla gelen öğrencilerin sorunlarına duyarlı olacak şekilde oluşturulacak, okul yöneticileri ve öğretmenler eğitimde bireyin tercihlerine daha çok saygı duyar hale gelecektir.

Ülkeler arasında artan ticaret hacmi toplumları, sadece ekonomik yönden değil, sosyal ve kültürel yönden de daha çok birbirine bağlayacak, ancak kültür transferi eskiden olduğu gibi güçlü olandan zayıf olana doğru gerçekleşmeye devam edecektir. Çok boyutlu ilişkiler ve artan karmaşıklık, entelektüel esnekliği olan, karmaşık sistemlere ilişkin bilgileri işleyebilen, disiplinler arası boyutta, yaratıcı ve soyut düşünebilen bireylerin yetişmesini gerektirecektir.

Geleceğin işgücünü hazırlamada okullara büyük iş düşecektir. Geleceğin çalışanlarından sadece iş değil, sosyal yaşama ilişkin sorumluluklar bakımından da ciddi beklentiler olacağından okullar, mesleki ve teknik eğitimin yanısıra, moral ve etik eğitime de yer vermek durumunda kalacaktır. Öğrenme okul duvarlarını aşacak, coğrafi ve kültürel sınırlar öğrenmede engelleyici olmaktan çıkacak, üniversiteler öğretmen yetiştirme programlarını yeniden gözden geçirecek, bireylerin birden fazla dili öğrenip konuşabilmesi önemli hale gelecektir.

Bireylerin sorunları tek başlarına çözme yeteneklerinde zayıflama olacağından, işbirliği ile öğrenme ve sorun çözme önemli hale gelecek, mevcut sorunlar, tek disiplinden değil, çok disiplinli bir yaklaşımla, farklı alanlardan kazanılan bilgi, kavram ve yeteneklerin eşgüdümlenmesi ile çözümlenecektir. İnsanlar arası diyalogun artmasına daha çok önem verilecek, sözlü ve sözlü olmayan iletişim becerilerinin öğretilmesi eğitimin önemli amaçları arasında yer alacaktır.

\section{KAYNAKLAR}

Argyris, C and Schön, D. A. (1996). Organizational learning II: The theory, metho, and practice USA: Addison- Wesley Publishıng Company.

Aytaç, T. (1999). Öğrenen Örgüt: Okul. Milli Eğitim 141: 75-78; Aktaran, Nartgün, Ş. S. (2002). Bilgi Toplumu Olma Yolundaki Türkiye'de Eğitim. Eğitim Araştırmaları 6: 131-135.

Aytaç, T. (2003). Okul Vizyonu Nedir, Nasıl Geliştirilir. Yönetimde Çağdaş Yaklaşımlar: Uygulamalar ve Sorunlar (2. Bask1), C. Elma., K. Demir (Ed). Ankara: Anı Yayıncilık 1-15.

Balc1, A. (1995). Örgütsel Gelişme. Ankara: Pegem Personel Eğitim Merkezi Yayın No: 18. 
Balc1, A. (2001). Etkili Okul ve Okul Geliştirme. Ankara: Pegem A Yayıncilik.

Bennett, R. (1999). Corporate strategy, London: Financial Times, Pitman Publishing, $\left(2^{\text {nd }} E d\right)$.

Biçer, T. (1999). NLP Kişisel Liderlik. İstanbul: Beyaz Yayınları.

Bilhan, S. (1996). Küreselleşme ve Ulusal Değerler. Türkiye 2. Eğitim Felsefesi Kongresi (23-26 Ekim). Van: Yüzüncü Yıl Üniversitesi Eğitim Fakültesi, 177-185.

Boydak, A. (2001). Öğrenme Stilleri. İstanbul: Beyaz Yayınları.

Doğan, H. (1997). Mesleki ve Teknik Eğitimin Yeniden Yapılandırılması. Ankara: Ankara Üniversitesi Eğitim Bilimleri Fakültesi Dergisi. 30 (1), $1-26$.

Doğan, E. (Ocak 2002). Eğitimde Küreselleşme. Eğitim Araştırmaları 6: 8798.

Garavan, T. (1997). The learning organization: A review and evaluation. The Learning Organization 4 (1) 18-29.

Kaçmazoğlu, H. B. (Ocak 2002). Doğu-Batı Çatışması Açısından Globalleşme. Ĕ̈itim Araştırmaları 6: 44-55.

Kaplan, Y. (1991) Giriş. Enformasyon Devrimi Efsanesi, (Der ve Çev: Y. Kaplan), İstanbul: Rey Yayınları, 1-10.

Karip, E. (1996). Etkili Eğitim Sistemlerinin Geliştirilmesi. Eğitim Yönetimi 2: $245-247$.

Kepenekçi Karaman, Y. (2003). Demokratik Okul. Eğitim Araştırmaları.3 (11),: 44-53.

Kolb, D. A. (1984). Experiential learning. New Jersey: Prentice Hall, Inc; Aktaran, Özden, Y. (2000). Ögrrenme ve Öğretme (4. Baskı) Ankara: Pegem A Yayıncilik.

Kurul Tural, N. (2004). Küreselleşme ve Üniversiteler. Ankara: Kök Yayıncilik.

Kuzgun, K; Sevim, S. A; Ersever, H; Akbalık, G; Pişkin, M ve Hamamcı, Z. (1997). Öğrencilerin Akademik Danışmanlarından Bekledikleri Görevler ve Danışmanların Görev Algıları. Ankara: Ankara Üniversitesi Eğitim Bilimleri Fakültesi Dergisi. 30 (1) 27-43.

Lashway, L.(1997). Visionary leadership. School Leadership Handbook For Excellenge ( $3^{\text {rd }}$ Ed), S. C: Smith and P.K: Piele (Eds). University of Oregon, 131-156. 
Leithwood, K., Leonard, L and Sharratt, L. (April 1998). Conditions fostering organizational learning in schools. Educational Administration Quarterly. 34, 2: 243-276.

Limerick, D., Passfield, R., \& Cunnington, B. (1994). Transformational change: towards an action learning organization. The Learning Organization. 1, (2), 29-40.

Maxwell, J. C. (1999). Liderlik Nitelikleri. (Türkçesi: İbrahim Şener), İstanbul:Beyaz Yayınları.

McGill, M.E., Slocum, J.W and Le1, D. (Summer1992). Management practices in learning organizations. Organizational Dynamic 21:5-16

Morrison, K. (1998). Management theories for educational chang.London: Paul Chapman Publishing Ltd.

Numanoğlu, G. (1999). Bilgi Toplumu-Eğitim-Yeni Kimlikler-II: Bilgi Toplumu ve Eğitimde Yeni Kimlikler. Ankara: Ankara Üniversitesi Eğitim Bilimleri Fakültesi Dergisi. 32, (1-2), 341-350.

Oswald, L, J. (1997). School-based management. school leadership handbook for excellenge, ( $3^{\text {rd }}$ Ed). S. C: Smith and P.K: Piele (Eds). University of Oregon, 181-203.

Öğüt, A. (2003). Bilgi Çağında Yönetim (2. Bask1), Ankara: Nobel Yayıncilık.

Özdemir, S. (2000). Eğitimde Örgütsel Yenileşme. (5. Baskı), Ankara: Pegem A Yayıncilik.

Özden, Y. (2000). Öğrenme ve Öğretme. (4. Bask1), Ankara: Pegem A Yayıncilik.

Özden, Y. (2002). Eğitimde Dönüşüm: Eğitimde Yeni Değerler. (4. Baskı), Ankara: Pegem A Yayıncilik.

Reddi, U. V. (1991). Sanayi Devriminin Aşılması. Enformasyon Devrimi Efsanesi. (Der ve Çev: Y. Kaplan), İstanbul: Rey Yayınları 345-370.

Senge, P. (1990). The fifth discipline: The art and practice of the learning organization. New York. In Morrison, K. (1998). Management Theories for Educational Change. London: Paul Chapman Publishing Ltd.

Slaus, I., Kokotovic, A. S., and Morovic, J. (2004). Education in countries in transition facing globalization-A case Study Croatia. International Journal of Educational Development 24: 479-494.

Smith, S. C and P1ele, P, K. (1997). Introduction. school leadership handbook for excellenge ( $3^{\text {rd }}$ Ed.) S. C. Smith And P. K. P1ele (Eds). University of Oregon 1-12. 
Tan, Ş., Kayabaş1, Y ve Erdoğan, A. (2002). Öğretimi Planlama ve Değerlendirme. (3. Bask1), Ankara: Anı Yayıncılık.

Tezcan, M. (1992). Ĕ̌itim Sosyolojisi. (8. Bask1). Ankara.

Tezcan, M. (1996). Küreselleşmenin Eğitimsel Boyutu. Türkiye 2. Eğitim Felsefesi Kongresi (23-26 Ekim). Van: Yüzüncü Yıl Üniversitesi Eğitim Fakültesi, 187-195.

Tezcan, M. ( Ocak 2002). Küreselleşmenin Eğitim Boyutu. Ĕ̈itim Araştırmaları 6: 56-60.

Toulmin, S. (1999). The ambiguities of globalization. Futures 31, 905-912.

Web, L. D., Metha, A., And Jordan, K.F. (1992). Foundations of American education. New York: Macmillan Publishing Company.

Wood, D. (1998). How Children Think and Learn. Second Ed. USA: Blackwell Publishers Inc,

Yıldırım, R. (2001). Öğrenmeyi Öğrenmek. İstanbul: Sistem Yayıncılık.

Yurdabakan, İ. (Ocak 2002). Küreselleşme Konusundaki Yaklaşımlar ve Eğitim. Eğitim Araştırmaları 6: 61-64. 